\title{
GAMLE OG KOMMENDE NUMRE
}

32. INDFØDTE behandler emnet indfødte, oprindelige folk eller 4.-verdensfolk inden for rammerne af de aktuelle antropologiske interessefelter kulturel identitet og kompleksitet. Indfødte folks vilkår i den moderne verden frembyder spørgsmål af både teoretisk, praktisk og politisk art.

33. DYR tager udgangspunkt i den ganske forbløffende mængde materiale, som den zoologiske verden bidrager med til vores kategoriseringer af omverdenen. I dette nummer bringes eksempler på, hvordan vi tænker, bruger, fremstiller og forestiller os dyr.

34. AIDS-forskningen i antropologien har udviklet sig fra en hjælpedisciplin for epidemiologien til kritiske analyser af videnskabelige og politiske „sandheder“ om hiv/aids og konstruktive undersøgelser af lokale forudsætninger for forebyggelse og omsorg.

35-36. FELTER er et festskrift med artikler om sjæleanliggender, etnografer, pornografi, repræsentation, rationalitet, identitet, kunst og verden, rum, metaforik, ceremonielle dialoger, ånder, kroppe og performance, halve mennesker, myter og kosmologi, objekter, totemisme, fysikkens erkendelseslære og menneskekulturerne mv.

\section{MELLEMØSTEN Udsolgt.}

38. BØRN har kun sjældent været del af det antropologiske genstandsfelt. Her belyses antropologiske perspektiver på børn og unge: Hvordan opfattes børn, hvad indebærer socialisering, og hvilke perspektiver og erfaringer har børn i forhold til deres omgivelser forskellige steder i verden?

39. MAD OG DRIKKE viser nye vinkler på de symbolske betydninger og sociale normer, som regulerer, hvad der indtages, hvornår, hvordan, sammen med hvem og i hvilke mængder.

40. OVERGANG ser på den antropologiske videnskab og den videnskabelige antropologi anno 2000. Hvilke erkendelser har overlevet 1980'ernes faglige selvransagelse, og hvilke epistemer hører fortiden til? Hvilke klassiske antropologiske dyder kan dårligt undværes, og hvad er forholdet mellem anvendt antropologi og grundforskning? 
41. ILLUSION har ofte negative konnotationer i retning af indbildning og forvrænget virkelighedsopfattelse. Her fokuseres på illusion som et empirisk forhold, dets kreative element i sociale og kulturelle sammenhænge samt dets virkemidler og konsekvenser.

42. DANSKHED Mens antropologer og andre analytikere dekonstruerer nationale fællesskaber, egenskaber og identiteter, polemiserer dette nummer ved at undersøge, hvordan og hvorvidt danskheden faktisk er: danske dufte, toner, omgangsformer, filmskatten og højskolesangbogen med mere. Er der tale om særligt danske forhold eller blot om forhold i Danmark?

43-44. SAMLING undersøger samlinger og samlere og overvejer begrebernes betydning for antropologien. Kategorier bringes sammen i nye konstellationer: museale dyrekategoriseringer, frimærkesamlinger, etnografiske samlinger, komplette samlinger, plane-spottere, klunsere, jæger-samlere og kunstsamlere.

45. KRITIK sætter fokus på den engagerede videnskab og videnskabsmand. Kritisk antropologi er ikke ny, men øget forskning og deltagelse i løsning af samfundsproblemer synes at skærpe den kritiske bevidsthed og kravet om stillingtagen. Hvad betyder det for den videnskabelige erkendelse og metode?

46. VOLD undersøger, hvorledes vold indgår i menneskers forestillinger og dagligliv. Temaet præsenterer et kontinuum af vold - mellem enkelte individer til vold omfattende en hel befolkning og afspejles i artikler om vold mod kvinder, overgreb på indfødte folk, civile lynchninger, borgerkrig, befrielseskrig og statsterror.

47. BYER I undersøger med bidrag fra antropologer, litterater, arkitekter og kunstnere en række konkrete byer og overvejer fænomenets betydning for antropologien. Forskelligartede byundersøgelser udfoldes i beskrivelserne af Abomey, Hanoi, Hby, Honolulu, København, København, Marseille, Máskat, Montreal og Mumbai.

48. BYER II undersøger med bidrag fra antropologer, litterater, arkitekter og kunstnere en række konkrete byer og overvejer fænomenets betydning for antropologien. Forskelligartede byundersøgelser udfoldes i beskrivelserne af Nuuk, Paris, Rio de Janeiro, Sarajevo, Shanghai, Skopje, Sun City, Sun City, Teheran og Århus.

49. PENGE handler om fjer, muslingeskaller, medaljoner, jetoner, betalingskort, bankoverførsler, mønter, sedler og andre værdier, som vises frem, gemmes væk, øremærkes og udveksles. Penge påvirker relationer og samfund og er derfor anledning til moralske og politiske problemstillinger om fællesskab og individualitet, magt og afmagt, ulighed og hierarki, følelse og marked. 
50. SLAEGTSKAB er som antropologisk forskningsfelt i de sidste årtier blevet kraftigt udfordret. Nye betingelser forårsaget af udviklingen inden for den lægevidenskabelige forplantnings- og genteknologi samt presset fra ændrede globale forhold, gamle og nye krige og sygdomsepidemier skaber rum for helt nye kreative tankegange og praksis i slægtssammenhæng.

51. ARBEJDE er et ,institutionaliseret" begreb, i den forstand at betydningen af ordet ikke er noget, vi almindeligvis tænker over, men nærmere noget, vi tænker med. Det giver anledning til overvejelser om og perspektiver på, hvordan arbejde skal begribes, samt hvordan begrebet tillægges mening i forskellige sociale og kulturelle sammenhænge - $\mathrm{i}$ en tid, hvor arbejdet synes at fylde stadig mere $\mathrm{i}$ vores liv og bevidsthed.

52. HUKOMMELSE er et socialt fænomen med et vigtigt politisk aspekt. Udtrykt i repræsentationer af fortiden danner hukommelse, social og kollektiv, udgangspunktet for et samfunds selvforståelse og legitimering. Et samfunds ,hukommelse" refererer ikke nødvendigvis til et verificerbart fænomen i fortiden. Den kollektive hukommelse er kreativt skabende og udtrykker sig ud over i samfundsformer i materiel kultur og i kroppe.

53. KOGNITION tager bestik af den „,kognitive revolutions“ betydning for aktuel antropologisk forskning. Værdien af dette nye teoretiske paradigme demonstreres og diskuteres i antropologiske analyser af religion, sprogtilegnelse, drømme, videnskabelig viden m.m.

54. LYD Udsolgt.

55. PERSON er ikke i sig selv antropologiens centrale omdrejningspunkt, det er derimod relationen mellem mennesker. Felten er fuld af mennesker, som vi umiddelbart identificerer som særskilte personer med egne livshistorier og -mål. Men hvad er egentlig en person? Hvordan skal vi forstå forholdet mellem individet og det sociale? Eksisterer der et „vi“ før et ,jeg“ - eller forholder det sig omvendt? Hvorledes håndterer antropologien møder mellem forskellige personopfattelser? Nummeret undersøger sådanne spørgsmål og de metodiske, teoretiske og politiske udfordringer, der følger heraf.

56. KULTURMØDE bruges i stigende grad til at beskrive og forklare, hvordan personer med forskellig etnisk, kulturel eller national baggrund bringes sammen og undertiden støder sammen. Begrebet „kulturmøde“ blev fundet analytisk ufrugtbart og derfor opgivet i antropologien i 1960'erne. I de senere år har ikkeantropologiske kulturstudiefag været med til at sætte nye dagsordener for, hvilke temaer og angrebsvinkler der kan være relevante for at forstå det mudrede felt, som man - i mangel af bedre? - på ny betegner kulturmøder. 
57. LOV OG RET Krav og ønsker fra individer og hele befolkningsgrupper formuleres i stigende grad inden for rammerne af et rettighedssprog, og en retlig forståelseshorisont spiller en stadig større rolle. Hvordan påvirker denne udvikling antropologiske studier af lov og ret? Dominerer rettighedsdiskursen i lige så høj grad på det empiriske plan som på det ideologiske? Er rettigheder mere tale end handling? Og hvordan spiller andre, ikke-legale forestillinger om retfærdighed sammen med retssamfundets juridiske univers?

58. SYGDOM vil belyse sammenhænge mellem forskellige fællesskabers/kulturers sygdomsopfattelser og håndteringer af sygdomme: Hvilke konflikter og løsninger opstår i og mellem forskellige fællesskaber, og hvilken placering gives eller tiltager de syge sig? Hvordan medvirker fællesskaberne til produktionen af sygdom, og hvilke muligheder har såvel det samlede fællesskab som de enkelte individer for at forebygge og behandle sygdomme?

59/60. HUS OG HJEM Hjemmet udtrykker et forhold mellem mennesker og mellem mennesker og materialitet, her især huset, som er ladet med betydning $i$ form af bl.a. tilhørsforhold og ejendomsret. Det understøtter identitet og fællesskaber i form af familieliv, men er også platform for differentieringer mellem køn og generationer. Hjemmet er kort sagt et socialt og kulturelt fænomen, som udfoldes i form af forskellige praktikker - det er noget, man gør.

61. MAGI spillede en vigtig rolle i den klassiske antropologi som en indfaldsvinkel til forståelsen af de indfødtes særlige symbolske og rituelle handlinger for at nå ønskede mål. Siden er det blevet almindeligt at betragte magi mere bredt som et af mange forsøg på at håndtere usikkerhed i det moderne samfund. Magi kan således betegnes som en særlig form for menneskelig handling, hvor bestemte ord, genstande eller fænomener tillægges en indflydelse eller kraft, som ligger ud over ordene, genstanden eller fænomenet i sig selv. Magi er det kreative felt, hvor ønsker og håb kan udtrykkes og måske lede til eftertragtede mål.

62. SKOLE Skolen vil altid være et udtryk for et bestemt samfund med dets særlige værdier og strukturer. Den vil have til hensigt at bidrage til formationen af dette samfund ved at søge at skabe gode borgere. Derfor udgør skolen en arena, hvor der dagligt kæmpes om, hvilke kulturelle værdier, hvilken fortolkning af historien og hvilke samfundsmæssige normer der skal være gældende. Skolen bidrager dermed til komplicerede eksklusions- og inklusionsprocesser både i materiel, social og kulturel forstand og dermed til konstruktionen af forskellige former for medborgerskab.

63. FREMTID. Orienteringen mod fremtiden er en orientering mod verden med konkrete udtryk. Forholdet til fremtiden kan ses som et udgangspunkt for handling. Samtidig er uvished og mangel på kontrol over fremtiden en realitet 
for store dele af verdens befolkning. Ideen om fremtiden kan derfor også være præget af desillusion, magtesløshed og håbløshed.

64. KLIMA Antropologien har gennem tiden beskæftiget sig med økologi som kulturelt og politisk fænomen og i det hele taget stadig afsøgt grænserne eller gensidigheden mellem natur og kultur. Klimaforandringerne tvinger endnu en gang antropologer til at udforske forholdet mellem mennesker og deres omgivelser, når ekstreme vejrbegivenheder, ændringer i årstidsmønstre, udsving i forekomster af naturressourcer og andet er blevet hverdag for mennesker kloden rundt.

65-66. TAVSHED Det kan undertiden være svært at identificere tavsheder i en aktuel, dominerende tradition, fordi vi typisk er en del af den. Men man kan uforvarende komme til at tale om det usigelige, og andres reaktioner vil snart gøre en opmærksom på, at man er ude i noget farligt. Man vil måske blive tiet ihjel eller disciplineret på anden vis. Tavsheder er ofte foruroligende og sigende. Men hvad siger de? Hvad dækker de over?

67. VERDEN(ER) Udsolgt.

68. OVERSKRIDELSER sætter fokus på et af antropologiens klassiske begreber (transgression) og udforsker forholdet mellem grænse og overskridelse og de bevægelser i kategoriseringssystemer og mulighedsrum, det medfører at krydse en grænse eller trodse et forbud. Hvad er overskridelser, og hvad kan begrebet bruges til? Er det grænserne, der fremhæver overskridelserne, eller overskridelserne, der fremhæver grænserne? Hvordan bruges begrebet overskridelse i nutidigt antropologisk arbejde?

69. FAENOMENOLOGI belyser krops- og hverdagsfænomenologiens rolle i antropologisk teorihistorie og diskuterer og illustrerer traditionens metodiske og analytiske potentiale og begrænsninger. Et centralt mål for den fænomenologisk inspirerede forskning er at redegøre for de kulturelle grundantagelser og kropsliggjorte færdigheder, der organiserer menneskets prærefleksive engagement med omverdenen. Denne ambition rejser vigtige metodologiske spørgsmål omkring produktion og skriftlig formidling af viden om de aspekter af det sociale liv, der normalt undslipper refleksion og fortolkning.

70. OPTIMERING sætter fokus på menneskets stræben efter at selvudvikle, forandre og forbedre ved hjælp af en mangfoldighed af teknologier og medicinske produkter og servicer, som får afgørende betydning for menneskers selvforståelse og gør kroppen, livet og selvet til et personligt projekt. Tendensen er særligt tydelig inden for sundhed, selvudvikling og kropslig og mental perfektion. Temanummeret går i dybden med eksempler på optimeringspraksisser og de sociale og kulturelle sammenhænge, de eksisterer i, og undersøger, hvordan de forskellige 
teknikker og praksisser påvirker hverdagsliv og forståelsen af, hvad det vil sige at være menneske.

71. BEHANDLING stiller skarpt på begrebet behandling, som synes at være det umiddelbare og selvfølgelige svar på mange og meget forskelligartede sociale problemer i dagens Danmark. Hvad forventes samfundet at tilbyde som modtræk til eller afhjælpning af problemer som $\mathrm{fx}$ alkoholmisbrug, narkomani, ludomani, spiseforstyrrelser, sexafhængighed og vold? Svaret er behandling. Et ansvarligt samfund kan ikke undlade at tilbyde behandling. Men hvad er behandling egentlig for en størrelse? Hvad betyder behandling? I hvilken udstrækning giver det mening at tale om behandling af diverse identificerede sociale problemer?

72-73. VELF/ERDSSTATEN præsenterer antropologiske bud på, hvordan velfærdsstaten, dens udvikling og forandringer kan forstås. Med udgangspunkt $\mathrm{i}$ Ove Kaj Pedersens bog Konkurrencestaten (2011) vil temanummeret diskutere konkrete empiriske cases fra de forskellige sektorer af velfærdsstaten og samfundslivet.

74-75. INNOVATION fremlægges og analyseres typisk ud fra et vestligt markedsorienteret perspektiv med fokus på økonomisk værdiskabelse. Dette nummer præsenterer antropologiske perspektiver på innovation og belyser innovative praksisser og forståelser på tværs af etnografiske kontekster. Det byder på 1) kritiske analyser af innovation som begreb i nutidens markedsorienterede samfund, 2) antropologiske bidrag fra vestlige og ikke-vestlige samfund og 3) diskussioner af en tilsyneladende tæt kobling mellem innovation og antropologi, herunder konkrete eksempler på antropologers arbejde med innovation.

76. GENRE udspringer af MEGA-seminaret i 2015, hvor arrangørerne slog et slag for en debat om antropologiske genreeksperimenter under rubrikken ,alvorlig leg“. Målet for temanummeret er at fortsætte den ,alvorlige leg“ med praksis og fremstilling. Det vil derfor være en platform for forsøg med og refleksioner over nye etnografiske metoder og eksperimenterende fremstillingspraksis.

77. ANTROPOLOGISK ETIK diskuterer vores rolle som forskere og stiller spørgsmålet: Hvem producerer vi egentlig viden for, og hvad er de etiske, sociale og politiske konsekvenser af vores forskningspraksis? Nummeret tager afsæt $\mathrm{i}$ nyere debatter om antropologiens relevans. Hvordan udvælger vi bestemte forskningsområder, og hvis interesser reflekterer det? Hvordan navigerer vi mellem forskelligartede krav til vores forskning? Hvad vil det egentlig sige, at antropologi som akademisk disciplin er forpligtet på sine felter?

78. DYSTOPIER Vi lever i en tid, hvor dystopier er blevet en fremherskende politisk teknologi. Dette nummer sætter fokus på dystopierne og særligt brugen 
af skræmmende skildringer af samfundsformer og scenarier i forskellige sociale og politiske sammenhænge. Det analyserer således dystopier - i politik, i miljø og klima, i religion og teknologi, deres form, iscenesættelse og politiske anvendelse. Hvordan kan vi beskrive og begribe de refleksioner over menneskets, naturens og samfundets skrøbelighed, som dystopierne indebærer? Og hvad er effekten af dystopier som ny politisk teknologi?

79. DATA Hvordan identificeres og indhentes data, og hvordan behandles data implicit og eksplicit analytisk? Og hvad sker der, når data bliver „,big“? Temanummeret beskæftiger sig med nye tilgange til og forståelser af videnskabelige data i antropologien og samfundsvidenskaberne i bredere forstand. I antropologien arbejdes der på forskellige måder med data, og temanummeret vil bringe disse forskellige måder frem i lyset samt diskutere og måske udvide rammerne for, hvad antropologisk viden kan bestå i.

80. UNDSKYLD Undskyldninger har fået stadig mere plads i nationale selvfortællinger. Flere stater er gået ind i arbejdet med at adressere de mere tvivlsomme kapitler i deres historie. Fortidens kolonimagtslande har delvist påtaget sig skyld for tidligere henlagte forbrydelser, for eksempel Frankrigs undskyldning til dets tidligere caribiske kolonier og statsminister Lars Løkke Rasmussens tilnærmelsesvise undskyldning for Danmarks rolle i slavehandlen i Dansk Vestindien. Dette nummer omhandler hele og halve undskyldninger, for eksempel i forbindelse med postkoloniale familiehistorier og repatriering af kulturarv.

81-82. TEKNOLOGI undersøger samspillet mellem mennesker og teknologi. Feltet spænder vidt fra fænomener som robotter, droner, overvågning og bioteknologi til energi, klima, transport, sociale medier og medicinske teknologier. Teknologi har altid været en del af det antropologiske projekt, men i nyere tid har det også givet anledning til faglig specialisering, der optræder under navnet teknoantropologi.

83. ARTER Fokus på (andre) arter inviterer til at kulegrave, hvad vi ved eller påstår at vide om mennesket, dets klassifikationer og relationer - og dets forhold til alt det, som i forskellige perioder har ligget uden for det menneskelige. I dette temanummer vil vi derfor kaste lys over nogle af de måder, hvorpå arter indgår i nye sociale relationer.

84. BØN Hvad vil det sige at bede? Hvilke ideer om virkning og virkelighed er indlejret i forskellige former for bønspraksis? Og hvordan kan bøn fungere som en komparativ ramme for en antropologisk beskæftigelse med sociale dynamikker? Disse temaer ønsker vi at stille skarpt på i dette temanummer gennem en udforskning af konkrete typer af engagement med bøn. 
85. VIRUS „En tsunami af virus truer“, kan man læse i medierne. COVID-19 har ramt os i foråret 2020, og de fleste har fået vendt op og ned på deres liv nærmest fra den ene dag til den anden. Hvad gør coronakrisen ved folk i Danmark og resten af verden? Hvordan reagerer de på smittefare og usikkerhed? Hvad gør den ved folks oplevelse af staten som markant aktør? Sker der en aktualisering af „samfundssind“ og nationalfølelse? Hvordan fungerer balancen mellem tvang og frivillighed? Hvad findes af konspirationsteorier?

86. ALDRING Aldring er et voksende antropologisk forskningsfelt. Dels er aldring ikke en tilstand, men en proces, som erfares hele livet, dels er aldring et uafværgeligt biologisk fænomen, hvis tolkning afhænger af den kulturelle og sociale kontekst. Hvordan formes aldring og alderdom i forhold til familien eller lokalsamfundet eller i mødet med sundhedssystemet og plejesektoren? Hvordan erfarer de ældre egen aldring? Hvordan rolle spiller faktorer som køn, familieforhold eller social baggrund for den enkeltes håndteringsstrategier? 